\title{
PENGARUH LABA BERSIH, ARUS KAS DAN RETURN ON EQUITY TERHADAP HARGA SAHAM DALAM INDEKS INFOBANK15
}

\author{
Jhon Lismart Benget. P \\ Fakultas Ekonomi, Universitas Prima Indonesia \\ jhonlismart@gmail.com
}

\begin{abstract}
The purpose of this study is to examine the effect of net income, operating cash flow, investment cash flow, funding cash flow and return on equity on stock prices in the infobank15 index. The population of this study is the infobank15 index banking shares which were listed on the Indonesia Stock Exchange in 2016-2018. The sample used in this research is purposive sampling technique. The results of this study indicate that simultaneously net income, operating cash flow, investment cash flow, funding cash flow and return on equity affect the stock price in the infobank15 index. Partially, this study show only net income have an effect on the stock price while operating cash flow, investment cash flow, funding cash flow and return on equity have no significant effect on the stock price in the infobank15 index.
\end{abstract}

Keyword: Net Profit, Cash Flow, Return On Equity, Stock Price

\section{PENDAHULUAN}

Salah satu alternatif bagi perusahaan untuk memperoleh tambahan dana adalah melalui pasar modal. Pasar modal adalah sarana untuk mempertemukan pihak yang memiliki kelebihan dana dan pihak yang memerlukan dana. Bagi pihak yang mengalami kekurangan dana, setelah dana diperoleh maka dapat melakukan ekspansi untuk mengembangkan perusahaan. Bagi pihak yang memiliki kelebihan dana akan berinvestasi pada suatu perusahaan dan berharap mendapatkan keuntungan atas dana yang telah diinvestasikan. Investor agar mau berinvestasi pada suatu perusahaan akan memilih perusahaan mana yang akan memberikan keuntungan dimasa akan datang. Untuk memilih perusahaan yang terbaik investor harus menganalisis kinerja perusahaan yang memiliki prospek baik ke depan. Kinerja suatu perusahaan akan terlihat dari harga saham perusahaan tersebut. Semakin baik kinerjanya maka akan semakin banyak investor yang berinvestasi pada perusahaan tersebut. Keberhasilan suatu perusahaan akan tercermin dari harga saham perusahaan. Semakin baik kinerja perusahaan akan membuat investor banyak berinvestasi pada perusahaan tersebut yang pada akhirnya akan meningkatkan harga saham. Sebaliknya semakin buruk kinerja perusahaan akan membuat investor menjual saham perusahaan tersebut yang pada akhirnya akan menurunkan harga saham. Investor memerlukan informasi tentang kinerja perusahaan agar dapat menganalisis perusahaan. Informasi kinerja perusahaan dapat dilihat dari laba yang diperoleh. Informasi laba yang diperoleh bisa dijadikan dasar untuk menilai seberapa besar keuntungan suatu perusahaan pada periode tertentu. Semakin baik kinerja perusahaan maka akan meningkatkan harga saham. Hal ini didukung oleh penelitian yang dilakukan oleh Hardianto (2006) yang menyatakan bahwa laba bersih memiliki pengaruh terhadap harga saham.

Informasi lain yang dapat digunakan untuk menganalisis perusahaan yaitu melalui laporan arus kas. Laporan arus kas merupakan laporan yang menyajikan aliran kas yang berasal dari aktivitas 
operasi, aktivitas investasi dan aktivitas pendanaan. Penelitian yang dilakukan oleh Arsianti dan Rahim (2015) menyatakan bahwa arus kas berasal dari aktivitas investasi berpengaruh terhadap harga saham. Penelitian yang dilakukan oleh Dana, Purnami \& Giri (2018) menyatakan bahwa arus kas berasal dari aktivitas pendanaan berpengaruh terhadap harga saham. Selain itu penelitian yang dilakukan oleh Santoso dan Rahayu (2014) menyatakan bahwa arus kas berasal dari aktivitas operasi berpengaruh terhadap harga saham.

Untuk menganalisis perusahaan, selain melihat laporan keuangan, juga bisa dengan menggunakan analisis rasio keuangan yaitu dengan menggunakan Return On Equity yang menggambarkan sejauh mana kemampuan perusahaan dalam menghasilkan laba yang bisa diperoleh pemegang saham. Penelitian yang dilakukan oleh Mustofa dan Pardiman (2016) menyatakan bahwa Return On Equity berpengaruh positif dan signifikan terhadap harga saham. Return On Equity yang tinggi diperoleh suatu perusahaan menggambarkan kinerja yang baik dalam mengelola ekuitas perusahaan.

Pada penelitian terdahulu yang telah diuraikan ditemukan beberapa hasil penelitian yang berbeda dalam meneliti pengaruh laba bersih, arus kas operasi, arus kas investasi, arus kas pendanaan dan Return On Equity terhadap harga saham. Penelitian yang dilakukan oleh Santoso dan Rahayu (2014) menyatakan bahwa laba bersih memiliki pengaruh signifikan terhadap kenaikan harga saham namun berbeda dengan hasil penelitian yang dilakukan oleh Dana (2018). Penelitian yang dilakukan oleh Santoso dan Rahayu (2014) menyatakan bahwa arus kas operasi memiliki pengaruh signifikan terhadap harga saham sedangkan penelitian yang dilakukan oleh Dana (2018) menyatakan bahwa arus kas operasi tidak berpengaruh signifikan terhadap harga saham. Penelitian yang dilakukan Asrianti dan Rahim (2015) menyatakan bahwa arus kas investasi berpengaruh positif dan signifikan terhadap harga saham sedangkan penelitian yang dilakukan oleh Santoso dan Rahayu (2014) menyatakan bahwa arus kas investasi tidak memiliki pengaruh terhadap harga saham. Penelitian yang dilakukan Dana (2018) menyatakan bahwa arus kas pendanaan memiliki pengaruh terhadap harga saham sedangkan penelitian yang dilakukan oleh Santoso dan Rahayu (2014) menyatakan bahwa arus kas pendanaan tidak memiliki pengaruh terhadap harga saham. Penelitian yang dilakukan Mustofa dan Pardiman (2016) menyatakan bahwa Return On Equity berpengaruh positif dan signifikan terhadap harga saham sedangkan penelitian yang dilakukan oleh Munira, dkk (2018) menyatakan bahwa Return On Equity tidak berpengaruh signfikan terhadap harga saham.

Dari hasil-hasil penelitian diatas terlihat adanya inkonsistensi hasil penelitian yang membuat peneliti termotivasi untuk melakukan penelitian tentang pengaruh laba bersih, arus kas operasi, arus kas investasi, arus kas pendanaan dan Return On Equity terhadap harga saham sektor perbankan yang terdaftar dalam indeks infobank15. Sektor perbankan memiliki peranan strategis dalam perekonomian sehingga sektor ini memiliki prospek positif. Pemilihan indeks infobank15 dikarenakan indeks ini terdiri dari 15 saham perbankan yang memiliki faktor fundamental yang baik dan likuiditas perdagangan yang tinggi.

Berdasarkan berbagai uraian diatas, peneliti akan melakukan penelitian dengan judul "PENGARUH LABA BERSIH, ARUS KAS DAN RETURN ON EQUITY TERHADAP HARGA SAHAM DALAM INDEKS INFOBANK15".

\section{KAJIAN LITERATUR}

\section{Laporan Keuangan}

Berdasarkan PSAK No. 1 (Revisi 2009) tujuan laporan keuangan adalah memberikan informasi mengenai posisi keuangan, kinerja keuangan dan arus kas entitas yang bermanfaat bagi pengguna laporan keuangan. Laporan keuangan terdiri dari: 
1. Laporan posisi keuangan.

Laporan posisi keuangan adalah daftar yang sistematis dari aset, utang dan modal pada tanggal tertentu yang dibuat pada akhir tahun.

2. Laporan laba rugi komprehensif.

Laporan laba rugi komprehensif adalah ikhtisar mengenai pendapatan dan beban suatu entitas untuk periode tertentu sehingga dapat diketahui laba atau rugi yang diperoleh.

3. Laporan arus kas.

Laporan arus kas adalah laporan yang menyajikan informasi tentang arus kas masuk dan arus kas keluar untuk suatu periode tertentu.

4. Laporan perubahan ekuitas.

Laporan perubahan ekuitas adalah laporan yang menunjukkan perubahan ekuitas untuk periode tertentu.

5. Catatan atas laporan keuangan.

Catatan atas laporan keuangan merupakan laporan yang berisi informasi tambahan atas apa yang disajikan dalam empat laporan diatas.

\section{Laba Bersih}

Menurut Sharpe, et.al (1995) dalam Hardianto (2006), laba bersih adalah selisih pendapatan dan beban. Menurut Hery (2013), laba bersih berasal dari transaksi pendapatan, beban, keuntungan, dan kerugian. Menurut Santoso (2014), laba bersih adalah pendapatan bersih perusahaan baik berasal dari kegiatan operasional maupun non operasional, setelah dikurangi pajak penghasilan $(\mathrm{PPh})$, yang dapat menambah modal pemilik. Berdasarkan beberapa pendapat diatas dapat disimpulkan bahwa laba bersih merupakan pendapatan bersih suatu perusahaan pada periode tertentu yang disajikan dalam laporan laba rugi.

Bagi investor, informasi laba bersih yang diperoleh dapat dijadikan dasar untuk menilai kinerja suatu perusahaan dan memprediksi imbalan investasi yang akan diperoleh ketika berinvestasi pada suatu perusahaan (Tandelin, 2010).

\section{Arus Kas}

Informasi arus kas dapat dilihat dari laporan arus kas yang diterbitkan oleh perusahaan. Menurut Martani (2014) laporan arus kas merupakan laporan yang menyajikan informasi tentang arus kas masuk dan arus kas keluar dan setara kas suatu entitas untuk periode tertentu. Melalui laporan arus kas, pengguna laporan dapat mengetahui bagaimana suatu perusahaan dapat menghasilkan dan menggunakan kas. Menurut Tandelin (2010) laporan arus kas merupakan laporan yang memuat aliran kas yang berasal dari tiga sumber yaitu aktivitas operasi, aktivitas investasi dan aktivitas pendanaan.

Menurut PSAK 2 (Revisi 2009) laporan arus kas diklasifikasikan berdasarkan aktivitas sebagai berikut:

1. Aktivitas Operasi

Aktivitas operasi adalah aktivitas penghasil utama pendapatan perusahaan dan aktivitas lain yang bukan merupakan aktivitas investasi dan pendanaan.

2. Aktivitas Investasi

Aktivitas investasi adalah aktivitas berupa perolehan dan pelepasan aset jangka panjang serta investasi lain yang tidak termasuk setara kas.

3. Aktivitas Pendanaan

Aktivitas pendanaan adalah aktivitas yang mengakibatkan perubahan dalam jumlah serta komposisi kontribusi modal dan pinjaman suatu perusahaan. 


\section{Return On Equity}

Selain melihat laporan keuangan perusahaan, analisis perusahaan dapat dilakukan dengan cara menggunakan analisis rasio keuangan. Salah satu indikator yang penting untuk menilai kinerja perusahaan adalah dengan melihat pertumbuhan laba perusahaan. Rasio keuangan yang digunakan yaitu Return On Equity.

Menurut Tandelin (2010) Return On Equity menggambarkan sejauh mana kemampuan perusahaan bisa menghasilkan laba yang bisa diperoleh pemegang saham. Menurut Hin (2008), Return On Equity menunjukkan tingkat keuntungan dari investasi yang ditanamkan pemegang saham. Berdasarkan beberapa pendapat diatas dapat disimpulkan bahwa Return On Equty adalah rasio yang menggambarkan perbandingan tingkat keuntungan yang dihasilkan perusahaan terhadap modal yang telah diinvestasikan oleh pemegang saham.

Menurut Tandelin (2010), rumus untuk menghitung Return On Equity suatu perusahaan adalah sebagai berikut:

ROE $=\frac{\text { Laba bersih setelah bunga dan pajak }}{\text { Jumlah Modal Sendiri }}$

\section{Saham}

Menurut Hin (2008), saham adalah surat berharga yang merupakan tanda kepemilikan seseorang atau badan terhadap suatu perusahaan. Menurut Syahyunan (2015), saham merupakan surat berharga yang menunjukkan kepemilikan seseorang atau badan terhadap suatu perusahaan. Jika seseorang membeli saham suatu perusahaan berarti telah menyertakan modal ke dalam suatu perusahaan sebanyak jumlah saham yang dibeli.

\section{Harga Saham}

Harga saham adalah nilai bukti penyertaan modal pada perseroan terbatas yang terdaftar di bursa efek suatu negara tertentu. Harga saham dapat berubah naik atau turun dengan begitu cepat. Hal tersebut terjadi tergantung penawaran dan permintaan di pasar modal.

Hipotesis penelitian sebagai berikut:

1. Laba bersih, arus kas operasi, arus kas investasi, arus kas pendanaan dan Return On Equity secara simultan berpengaruh terhadap harga saham dalam indeks infobank15.

2. Laba bersih, arus kas operasi, arus kas investasi, arus kas pendanaan dan Return On Equity secara parsial berpengaruh signifikan terhadap harga saham dalam indeks infobank15.

\section{METODE}

Jenis penelitian ini menurut tingkat eksplanasinya termasuk penelitian asosiatif hubungan kausal. Penelitian asosiatif adalah penelitian yang dilakukan dengan tujuan untuk mengetahui hubungan antara dua variabel atau lebih (Sugiyono dalam Lubis, 2015). Hubungan kausal adalah hubungan yang bersifat sebab akibat antara satu variabel terhadap variabel lain (Sugiyono, 2010). Penelitian ini dilakukan pada perbankan Indeks Infobank15 yang terdaftar di Bursa Efek Indonesia pada tahun 2016-2018. Data yang digunakan dalam penelitian ini menggunakan data sekunder berupa laporan keuangan perbankan Indeks Infobank15 yang terdaftar di Bursa Efek Indonesia pada tahun 2016-2018 dengan cara mendownload melalui situs www.idx.co.id.

Populasi dalam penelitian ini adalah saham-saham perbankan indeks infobank15 yang terdaftar di Bursa Efek Indonesia pada tahun 2016-2018. Sampel yang digunakan dalam penelitian ini yaitu perusahaan yang terdaftar dalam indeks infobank15 di Bursa Efek Indonesia selama tiga periode dari tahun 2016 sampai dengan tahun 2018. Pengambilan sampel dilakukan dengan teknik purposive sampling. Jumlah sampel yang digunakan dalam penelitian ini adalah 11 perusahaan. 


\section{Metode Analisis Data}

Metode analisis data yang digunakan dalam penelitian ini adalah analisis regresi linier berganda. Analisis data dilakukan dengan menggunakan software SPSS (Statistical Packages For Social Science). Analisis regresi linear berganda digunakan untuk mengetahui pengaruh variabel independen, yaitu laba bersih, arus kas operasi, arus kas investasi, arus kas pendanaan dan Return On Equity terhadap variabel dependen yaitu harga saham (Y).

Sebelum dilakukan analisis regresi berganda perlu dilakukan uji asumsi klasik yang meliputi uji normalitas, uji multikolonieritas dan uji heteroskedastisitas dan uji autokorelasi (Ghozali, 2005).

Persamaan yang diperoleh dalam analisis data adalah sebagai berikut:

$$
\mathrm{Y}=\mathrm{a}+\mathrm{b}_{1} \mathrm{X}_{1}+\mathrm{b}_{2} \mathrm{X}_{2}+\mathrm{b}_{3} \mathrm{X}_{3}+\mathrm{b}_{4} \mathrm{X}_{4}+\mathrm{b}_{5} \mathrm{X}_{5}+\mathrm{e}
$$

Dimana: Y; Harga Saham, a; Konstanta, b1, $\mathrm{b}_{2}, \mathrm{~b}_{3}, \mathrm{~b} 4$; Koefisien regresi; $\mathrm{X}_{1}$;Laba Bersih; X2; Arus Kas Operasi; $\mathrm{X}_{3}$; Arus Kas Investasi, $\mathrm{X}_{4}$; Arus Kas Pendanaan, $\mathrm{X}_{5}$; Return On Equity, e; Error.

\section{HASIL DAN DISKUSI}

\section{Uji Asumsi Klasik}

\section{Uji Normalitas}

Data telah terdistribusi normal dilihat berdasarkan uji Kolmogorov-Smirnov dengan nilai signifikan sebesar $0,422>0,05$.

\section{Uji Multikolonieritas}

Berdasarkan uji multikolonieritas diperoleh semua variabel independen memiliki nilai Tolerance lebih besar dari 0,1 dan nilai VIF lebih kecil dari 10. Dengan demikian pada model regresi tidak ditemukan masalah multikolonieritas.

\section{Uji Heteroskedastisitas}

Uji heterokedastisitas menunjukkan bahwa bahwa titik-titik menyebar ke atas dan ke bawah, maka model regresi tidak ditemukan adanya masalah heteroskedastisitas.

\section{Uji Autokorelasi}

Berdasarkan Uji autokorelasi menunjukkan bahwa tidak terdapat masalah autokorelasi.

\section{Hasil Analisis Regresi Linear Berganda}

Hasil analisis linear berganda dapat dilihat dari tabel berikut:

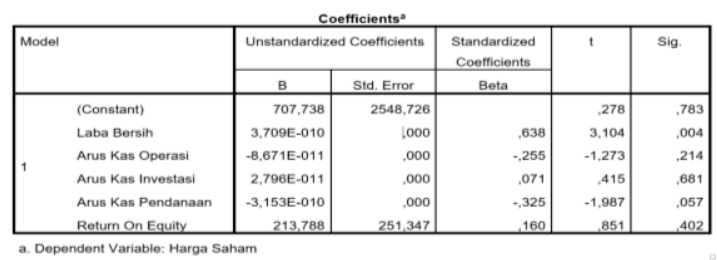

Sumber: Hasil Penelitian (Output SPSS)

Berdasarkan hasil pengolahan di atas dapat diperoleh persamaan regresi linear berganda sebagai berikut:

$\mathrm{Y}=\mathrm{a}+\mathrm{b}_{1} \mathrm{X}_{1}+\mathrm{b}_{2} \mathrm{X}_{2}+\mathrm{b}_{3} \mathrm{X}_{3}+\mathrm{b}_{4} \mathrm{X}_{4}+\mathrm{b}_{5} \mathrm{X}_{5}+\mathrm{e}$

$\mathrm{Y}=707,738+3,709 \mathrm{X}_{1}-8,671 \mathrm{X}_{2}+2,796 \mathrm{X}_{3}-3,153 \mathrm{X}_{4}+213,788 \mathrm{X}_{5}+e$ 
Dari persamaan regresi diatas dapat dianalisis sebagai berikut:

1. Konstanta (a) sebesar 707,738 menunjukkan bahwa jika variabel independen diasumsikan sama atau sama dengan 0 maka harga saham sebesar 707,738.

2. Koefisien laba bersih sebesar 3,709 menunjukkan bahwa setiap kenaikan $1 \%$ variabel laba bersih menyebabkan harga saham meningkat sebesar 3,709 dengan asumsi variabel lainnya tetap atau sama dengan 0 .

3. Koefisien arus kas operasi sebesar $-8,671$ menunjukkan bahwa setiap kenaikan $1 \%$ variabel arus kas operasi menyebabkan harga saham mengalami penurunan sebesar -8,671 dengan asumsi variabel lainnya tetap atau sama dengan 0 .

4. Koefisien arus kas investasi sebesar 2,796 menunjukkan bahwa setiap kenaikan $1 \%$ variabel arus kas operasi menyebabkan harga saham meningkat sebesar 2,796 dengan asumsi variabel lainnya tetap atau sama dengan 0 .

5. Koefisien arus kas pendanaan sebesar $-3,153$ menunjukkan bahwa setiap kenaikan $1 \%$ variabel arus kas pendanaan menyebabkan harga saham mengalami penurunan sebesar $-3,153$ dengan asumsi variabel lainnya tetap atau sama dengan 0 .

6. Koefisien Return On Equity sebesar 213,788 menunjukkan bahwa setiap kenaikan 1\% variabel Return On Equity menyebabkan harga saham meningkat sebesar 213,788 dengan asumsi variabel lainnya tetap atau sama dengan 0 .

\section{Hasil Uji Parsial (Uji t)}

Berdasarkan hasil pengujian maka secara parsial pengaruh masing-masing variabel independen terhadap variabel dependen dapat diuraikan sebagai berikut:

a. Variabel laba bersih mempunyai t hitung sebesar 3,104 lebih besar dari t tabel 2,051 dan nilai signifikan sebesar 0,004 lebih kecil dari alpha 0,05, sehingga dapat disimpulkan bahwa laba bersih berpengaruh terhadap harga saham.

b. Variabel arus kas operasi mempunyai t hitung sebesar -1,273 lebih kecil dari t tabel 2,051 dan nilai signifikan sebesar 0,214 lebih besar dari alpha 0,05, sehingga dapat disimpulkan bahwa arus kas operasi tidak berpengaruh terhadap harga saham.

c. Variabel arus kas investasi mempunyai t hitung sebesar 0,415 lebih kecil dari t tabel 2,051 dan nilai signifikan sebesar 0,681 lebih besar dari alpha 0,05, sehingga dapat disimpulkan bahwa arus kas investasi tidak berpengaruh terhadap harga saham.

d. Variabel arus kas pendanaan mempunyai t hitung sebesar -1,987 lebih kecil dari t tabel 2,051 dan nilai signifikan sebesar 0,057 lebih besar dari alpha 0,05, sehingga dapat disimpulkan bahwa arus kas pendanaan tidak berpengaruh terhadap harga saham.

e. Variabel Return On Equity mempunyai t hitung sebesar 0,851 lebih kecil dari t tabel 2,051 dan nilai signifikan sebesar 0,402 lebih besar dari alpha 0,05, sehingga dapat disimpulkan bahwa Return On Equity tidak berpengaruh terhadap harga saham.

\section{Hasil Uji Simultan (Uji F)}

Hasil uji F dapat dilihat pada tabel berikut:

\begin{tabular}{ll|r|r|r|c|c|}
\hline Model & & Sum of Squares & df & Mean Square & F & Sig. \\
\hline \multicolumn{1}{|l}{ Regression } & 538785240,573 & 5 & 107757048,115 & 4,533 &, $004^{\circ}$ \\
& Residual & 641780409,609 & 27 & 23769644,800 & & \\
& Total & 1180565650,18 & 32 & & & \\
\hline
\end{tabular}
a. Dependent Variable: Harga Saham
b. Predictors: (Constant), Return On Equity, Arus Kas Pendanaan, Arus Kas Investasi, Arus Kas
Operasi, Laba Bersih

Sumber: Hasil Penelitian (Output SPSS)

Berdasarkan tabel diatas diperoleh nilai $\mathrm{F}$ hitung sebesar 4,533 lebih besar dari $\mathrm{F}$ tabel 2,52 dan nilai signifikan uji $\mathrm{F}$ sebesar 0,004 lebih kecil dari alpha 0,05 sehingga dapat disimpulkan bahwa 
secara simultan laba bersih, arus kas operasi, arus kas investasi, arus kas pendanaan dan Return On Equity berpengaruh terhadap harga saham.

\section{Hasil Uji Koefisien Determinasi}

Hasil uji koefisien determinasi dapat dilihat pada tabel berikut:

\begin{tabular}{|l|l|r|r|r|r|}
\hline Model & \multicolumn{1}{|c|}{ Model Summary } \\
\hline 1 &, $676^{\mathrm{a}}$ &, 456 &, 356 & 4875,412 & 2,040 \\
\hline
\end{tabular}

a. Predictors: (Constant), Return On Equity, Arus Kas Pendanaan, Arus Kas Investasi,

Arus Kas Operasi, Laba Bersih

b. Dependent Variable: Harga Saham

\section{Sumber: Hasil Penelitian (Output SPSS)}

Berdasarkan tabel diatas diperoleh angka Adjusted $R$ Square sebesar 0,356 atau (35,6\%). Hal ini berarti bahwa sebesar 35,6\% variabel dependen (harga saham) dapat dijelaskan oleh variabel independen (laba bersih, arus kas operasi, arus kas investasi, arus kas pendanaan dan Return On Equity), sedangkan sisanya sebesar $64,4 \%$ dijelaskan oleh variabel lain yang tidak dimasukkan dalam penelitian ini.

\section{Pembahasan}

Hasil penelitian menunjukkan bahwa laba bersih berpengaruh terhadap harga saham. Hal ini sejalan dengan penelitian yang dilakukan oleh Santoso dan Rahayu (2014) yang menyatakan bahwa laba bersih memiliki pengaruh signifikan terhadap kenaikan harga saham. Semakin besar laba bersih perusahaan, semakin baik kinerja perusahaan yang akhirnya akan meningkatkan harga saham perusahaan. Hasil penelitian menunjukkan bahwa arus kas operasi tidak berpengaruh terhadap harga saham. Hasil ini sejalan dengan penelitian Dana (2018) menyatakan bahwa arus kas operasi tidak berpengaruh signifikan terhadap harga saham.

Hasil penelitian menunjukkan bahwa arus kas investasi tidak berpengaruh terhadap harga saham. Hal ini sejalan dengan Santoso dan Rahayu (2014) menyatakan bahwa arus kas investasi tidak memiliki pengaruh terhadap harga saham. Hasil penelitian menunjukkan bahwa arus kas pendanaan tidak berpengaruh terhadap harga saham. Hal ini sejalan dengan penelitian yang dilakukan Santoso dan Rahayu (2014) menyatakan bahwa arus kas pendanaan tidak memiliki pengaruh terhadap harga saham. Hasil penelitian menunjukkan bahwa Return On Equity tidak berpengaruh terhadap harga saham. Hal ini sejalan dengan penelitian yang dilakukan oleh Munira, dkk (2018) menyatakan bahwa Return On Equity tidak berpengaruh signfikan terhadap harga saham.

\section{KESIMPULAN}

\section{Kesimpulan}

Berdasarkan hasil penelitian yang telah diuraikan sebelumnya maka dapat diambil kesimpulan sebagai berikut:

1. Secara simultan laba bersih, arus kas operasi, arus kas investasi, arus kas pendanaan dan Return On Equity berpengaruh terhadap harga saham dalam indeks infobank15. 
2. Secara parsial hanya laba bersih yang berpengaruh terhadap harga saham sedangkan arus kas operasi, arus kas investasi, arus kas pendanaan dan Return On Equity tidak berpengaruh terhadap harga saham dalam indeks infobank15.

\section{REFRENSI}

Asrianti dan Rahim, Pengaruh Laba dan Arus Kas terhadap Harga Saham Perusahaan LQ 45 Di Bursa Efek Indonesia, Jurnal Akuntansi Aktual, Vol. 3. 2015.

Dana, Kadek S., A.A.S. Purnami, \& N. P.R. Giri, Pengaruh Komponen Arus Kas, Laba Perusahaan, Dan Return On Assets Terhadap Harga Saham Pada Perusahaan Manufaktur (Consumer Goods) yang Terdaftar Di Bursa Efek Indonesia Tahun 2014-2016. Warmadewa Economic Development Journal, Vol. 1. 2018.

Hardianto. Pengaruh Laporan Arus Kas dan Laba Bersih Terhadap Harga Saham Pada Perusahaan Food and Beverage yang Terdaftar Di PT BES (Bursa Efek Surabaya). Fakultas Ekonomi Universitas Airlangga Surabaya: 2006.

Ghozali, Imam. 2005. Aplikasi Analisis Multivariate dengan Program SPSS, Edisi Ketiga: Badan Penerbit Universitas Diponegoro, Semarang.

Hery, Teori Akuntansi Suatu Pengantar. Jakarta: Lembaga Penerbit Fakultas Ekonomi Universitas Indonesia. 2013.

Hin, L. Thian, Panduan Berinvestasi Saham. Elex media komputindo. 2008.

Ikatan Akuntan Indonesia, Standar Akuntansi Keuangan per 1 Juli 2009. Jakarta: Salemba Empat. 2009.

Lubis, Ade F. Metode Penelitian Akuntansi dan Format Penulisan Tesis. USU Press. 2015

Martani, dkk, Akuntansi Keuangan Menengah Berbasis PSAK, Jakarta: Salema Empat. 2012.

Munira, Pengaruh ROE dan DER terhadap harga saham perusahaan kertas di Bursa Efek Indonesia, Journal of Applied Business and Economics. Vol. 4. 2018.

Mustofa dan Pardiman, Pengaruh Return on Equity (ROE) Dan Return On Asset (ROA) Terhadap Harga Saham Perusahaan Manufaktur Sektor Makanan Dan Minuman Yang Terdaftar Di Bursa Efek Indonesia Tahun 2010-2012. Jurnal Profita. Edisi 3. 2016.

Sugiyono, Metode Penelitian Kuantitatif, Kualitatif dan R\&D. Penerbit Alafabeta. Bandung. 2010.

Santoso dan Rahayu, Pengaruh Informasi Laba Dan Arus Kas Terhadap Harga Saham (Studi Pada Perusahaan Yang Tercatat Di Indeks Sri Kehati Tahun 2010-2012). e-Proceeding of Management. Vol.1. Universitas Telkom, 2014. 
Syahyunan. Manajemen Keuangan: Perencanaan, Analisis dan Pengendalian Keuangan. Penerbit USU Press, 2015.

Tandelilin, Eduardus. Portofolio dan Investasi Teori dan Aplikasi. Edisi pertama. Yogyakarta : Kanisius, 2010.

www.idx.co.id 